\title{
Develop Scientific Inquiry Integrating into Project Practice Teaching of Innovative Curriculum for Vocational High School
}

\author{
Chin-Wen Liao, Yao-Tsung Chiang, Yi-Chen Chang, and Tsai-Ku Liao
}

\begin{abstract}
This study aims to enhance understanding and application to Scientific Inquiry for Vocational High School students by the method of scientific research. Integrate Scientific Inquiry into Project Practice courses for vocational education in order to expand students' vision and let them be used to self-learning and explore state-of-the-art technology to make them realize the impact on human lives. This study develops Innovative Curriculum of Scientific Inquiry integration for vocational education and uses them for Project Practice. By means of courses what students participate in personally, uplift their knowledge, technology and literacy of Scientific Inquiry. Develop the school-based and student-centered experiment to integrate Scientific Inquiry into Project Practice of Innovative Curriculum for vocational education and promote its $R \& D$ of teaching materials and curriculum evaluation to the relevant vocational high schools in central Taiwan.
\end{abstract}

Index Terms-Vocational high school, science inquiry, project practice, innovative curriculum about four key words or phrases in alphabetical order, separated by commas.

\section{INTRODUCTION}

How to train students with diverse abilities under globalization and develop school characteristics to face the rapidly-changing challenges at the same time, the most fundamental approach is proceed to develop and upgrade courses [1]-[3]. Multiple Intelligences Theory pointed out that human Intelligences comprising language, mathematics $\&$ logic, music, limbs use, space, interpersonal, Introspection and natural sciences are similar to traditional ethics, intelligence, physical, gregarious, art [4]. It is not easy for a single discipline to achieve the above multiple intelligence education. Educational goals of various disciplines in senior high schools consist of cognition goal, skill goal and affection goal. How to reach education goal of knowing \& doing affection through Instructional design, implementation and assessment that is long-term efforts and the focus of attention. Combining nature with culture characteristics and nurturing above-mentioned multiple intelligences with integration features, Senior High School Geography with natural Environment \& cultural landscape should be the first choice among all disciplines [5]-[8]. The spirit of inquiry

Manuscript received March 8, 2014; revised May 18, 2014. This work was supported in part by the Ministry of Science and Technology under Grants NSC 102-2511-S-018 -010.

The authors are with the Department of Industrial Education and Technology, National Changhua University of Education (NCUE), Taiwan (e-mail: tcwliao@cc.ncue.edu.tw, cytsung@gmail.com,yd3174@gmail.com, tsaikuliao@gmail.com). plays an important role in contemporary science education. "White Paper on Science Education" published by The Ministry of Education indicates that Characteristics of science education is about cultivation of scientific literacy and the meaning of science education is via scientific inquiry activity to make students obtain relevant knowledge \& skills, raising scientific thinking habits, engaging in discussion and argumentation according to the scientific method and solve problems by using the scientific knowledge \& skills [9]. Thus form the understanding of science essence and establish the spirit of science. American National Science Education Standards expressed that inquiry is multi-oriented activities including proceeding observations, proposing questions, reviewing book \& other information source, plans for conducting study [10], [11], reviewing what the known part is according to experimental evidence, using tools for collecting \& analyzing \& interpreting data, proposing answers, explaining and predicting, sharing conclusions with others, and so on. [12]

All of vocational students whether have the ability to integrate prospective emerging technology into Project Practice? Would like to make products of Project Practice with value and practicality if it is essential to own some conditions or basic abilities such as mathematical basis, humanities cultivation and theoretical aspects of technological research? Therefore hope to integrate exploring emerging technology into vocational courses, planning inquiry learning [13], enriching the basic science, introducing into professional disciplines, curriculum outline of technology integration and Project Practice, teaching sites, equipment $\&$ apparatus and propose the most feasible $\&$ the most effective mode to be references for schools to proceed teaching experiment and provide Implement of program Improvement [14], [15].

The twenty-first century is an information explosion, high-tech development, society changing rapidly and closely related International relations of new era. The goals of cross-century nine-year compulsory curriculum focus on cultivating lifetime learning of healthy citizens who possess integration capability of the humanities \& technology integration, active inquiry, solving the problem and using information and language, etc [16]. American National Science Standards (NSES) Definitions of Inquiry: "Inquiry is a procedure that scientists propose questions about the natural world, looking for answers and understanding deeply. It is not from cognitive of experts or other processes."American National Research Council in National Science Education Standards state inquiry as follows: Inquiry is the focus for science learning [12]. When participate 
inquiry, students describe an object or event, questioning, creating explanations \& testing them on the basis of current scientific knowledge and express their opinions. Students would like to identify their hypothesis, they have to apply logic \& critical thinking and even consider possible alternative explanations. In this case, students link scientific knowledge, reasoning and thinking skills to develop actively their understanding about science [17], [18].

$5 \mathrm{E}$, learning cycle of teaching mode is one typical representative of inquiry-based teachings [19]-[21]. Gardner first proposed the three-stage learning cycle theory and respectively was exploration, invention and discovery. After reforming several times by Lawson \& others, it finally evolved to be the five stages of learning cycles [22]. With constructivism characteristics, 5E learning cycle of teaching mode divided leanings into five stages and separately were Engage, Explore, Explain, Elaborate, Evaluate that developed by American BSCS. As shown in Fig. 1.
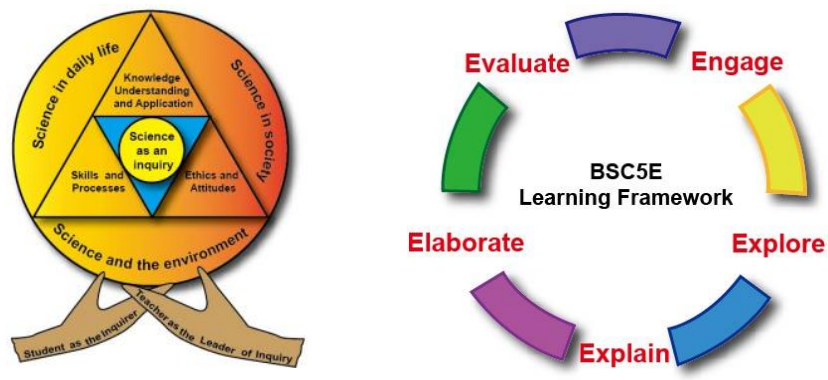

Fig. 1. Inquiry-based learning.

Survey of scientific inquiry learning: Harlen suggested two main methods of data collection to assess students' scientific inquiry learning including observing student behavior and analyzing students' written reports [23]. She said that not all students' inquiry skill data could observe and collect in the field. But students' written reports could usually provide useful information. For example, it described how students conducted observing, forecasting and planning. Harlen, Marco,Reed \& Schilling recommended several ways to assess students methods of scientific work [24]-[27]. Except observation, it was an effective method to refer to students' routine. In addition, Krajcik, Czerniak \& Berger thought that achievement of Science Project inquiry could demonstrate students' leanings; it could be used for assessment [28]-[30].

Comprehensive theory of literature: Realize science education in continuous development from the above discussed literature and the direction of development is student-centered learning [31]. With student-centered scientific inquiry, focus on process skills and concept learning at the same time. Learning of the relevant research, study always adopts qualitative methods and discussion on the teaching of scientific inquiry or individual parts among learning [32]. Literature discussion shows that qualitative research is helpful to investigate vocational students' the process and learning outcomes during their exploration activities. This research is expected to follow the above direction to explore vocational students' accumulating experiences in innovative teaching activities of Project Practice curriculum and then build architecture of scientific inquiry mode to provide teachers guidance to design scientific inquiry learning for students to make students practice scientific inquiry in order to achieve scientific concept of learning [33], [34].

\section{DESIGN AND IMPLEMENTATION}

\section{A. Research Framework}

In order to plan systematically outcomes assessment and promotion research of scientific inquiry integrated curriculum for vocational education to train students having scientific inquiry literacy. Research framework and constructs shown as Fig. 2. In order to conduct cooperation effectively with cooperative vocational schools and connect pertinently with experimental teaching activities to reach multiplier effects. In addition to grasp the direction of the entire program, convening a meeting timely and perform ongoing communication \& coordination with teachers \& executive team to ensure promoting project execution effectively.

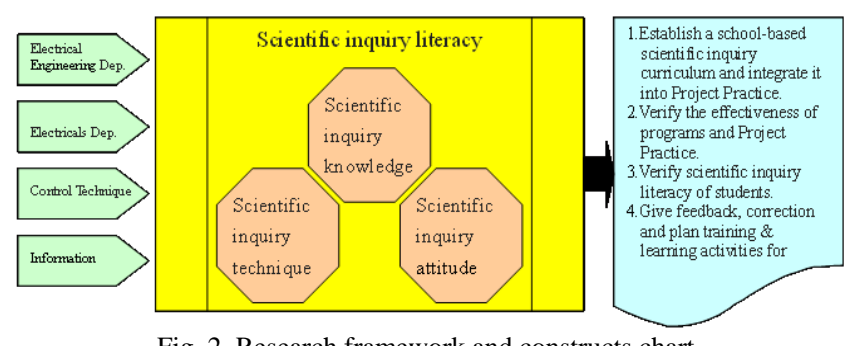

Fig. 2. Research framework and constructs chart.

In this study, there are four classes of students as research objects in AA vocational high school including Electrical Engineering Department, Electronics Department, Control Technique Department, and Computer Technique Department. By means of teaching basic knowledge of Scientific Inquiry curriculum and actually integrating it into implementing courses of Project Practice, let students understand theory and technology about Scientific Inquiry that contribute to the future development needs for education or employment.

\section{B. Research Methods and Procedures}

Research methods and conducting steps are as follows:

Research methods: 1. Document Analysis: Based on literature, for the purpose to realize deeply vocational schools about scientific inquiry courses and related documents. Thence collect the relative study, documents, recruitment announcement, etc. By content analysis, proceed capturing important information and attain completeness and correctness of the research topics. 2. Focus Group: According to research purposes, take statistical data of scientific inquiry courses and analysis of the development of teaching materials from schools as theoretical basis of this study. Through collection of literature \& relative research and comprehensive induction, use Focus Group to induce Interaction to make group members have enough participation and effect of impromptu reactions. Let them express, challenge and react to experience and interpretation of each member using the language that they are used to. 3 . Experimental Research: According to research purposes, 
take statistical data of scientific inquiry courses, analysis correction and confirm course objectives \& teaching materials from schools. Afterward this study will conduct execution of teaching system in experimental teaching methods. During the study, by means of quasi-experimental designs, third grade students are as objects from vocational high schools including Electrical Engineering Department, Electronics Department, Control Technique Department and Computer Technique Department. Randomly select the experimental group and the control group to perform teaching experiment by class. During teaching process, completely execute the result obtained from previous research such as teaching objectives, course outline, teaching strategies and assessment strategies. Record students' achievement and make a comparison at last. 4. Pannel Discussion: According to research purposes, take statistical data of scientific inquiry courses, analysis correction and confirm course objectives \& teaching materials from schools. Invite experts to conduct symposium, discussing and make the relevant amendments. Participating scholars and experts include industry practices, senior professionals of vocational high schools, science education experts, curriculum experts and educational administrative personnel, etc. Offer opinions to theory courses. Furthermore, survey and confirm some issues like learners at all levels their learning origin and characteristics, the adequacy of existing teaching resources devices to be a basis to revise courses connotation and related strategies. 5. Action Research: Action research contains 5 stages such as diagnosing problems, selecting scheme, seeking cooperation, executing implementation and evaluating response. Through action research members like school teachers, administrative personnel and researchers who work together, actually participating in action, systematically investigating and enhance teachers' ability of solving problems and then promote combination of educational theory and practicality to upgrade quality and efficiency of education. Action Research in the practical aspect, practitioners adopt specific actions and conduct research to improve the work content to the actual work situation. In the professional aspect, practitioners upgrade the quality of professional activity and effectively face the challenges of work.

Research procedures: 1. Develop emerging technology suited to cooperative vocational schools for using in courses and teaching materials of Project Practice. 2. Develop knowledge of Scientific Inquiry, literacy scales of skills and attitude and achievement assessment tools. 3. Revise teaching experiment of Scientific Inquiry integrating into Project Practice curriculums for Vocational High School students via the external and internal experts. 4. Develop Scientific Inquiry integrating into Project Practice of curriculums \& teaching materials suited to cooperative Vocational High School.

Research objects: Sampling from third grade students are as objects from Vocational High School including Electrical Engineering Department, Electronics Department, Control Technique Department, and Computer Technique Department in 2014. Develop Project Practice teaching of Innovative Curriculums.

\section{DATA ANALYSIS AND DisCUSSION}

\section{A. Curriculum Development Operations}

Curriculums are emerging technology integrating into curriculums teaching of Project Practice suited to Electrical Engineering Department, Electronics Department, Control Technique Department and Computer Technique Department. Hold course meeting each department and offer opinions and conclusions of the meeting resolutions to teacher professional learning community to discuss and perform. Therefore conduct four-stage planning according to the characteristics of the school as the follows:

Planning stage: Planning is to prepare for the course design; the main purpose is ideas communicating and curriculum framework establishing. Its contents include establishing planning team, collecting data, needs assessment, setting goals, building curriculum organization, establishing curriculum framework and setting planning schedule. Planning team is the core unit of curriculum development responsible for planning and promoting school-based curriculums.

Design stage: Prepare teaching subjects include general subjects, activity subjects and professional and internship courses. According to relevance of the unit course, arrange learning schedule \& procedure of curriculums. Finally integrate the curriculums of each subproject program including subject name, school year period, credits and compulsory or elective.

Schools aspect, have to prepare teacher deployment, equipment deployment \& teacher training for new design courses at the same time based on existing faculty and plant $\&$ equipment. Implementation stage: In order to make school planning curriculums reach to a predetermined target after implementation that schools should conduct communication and declaration with teaching teachers, taught students and parents to explain planning ideas, the education goal, future employment and graduation requirements [23]. According to educational goals teachers design teaching modules, course content and assessment criteria. According to personal career planning students select the most proper courses for their own development to learn.

Assessment stage: Curriculum assessment should be that throughout the course at any stage of development is in progress and is amended at any time. Evaluation methods of school-based curriculum development have three including achievement evaluation, process evaluation and content evaluation. Achievement evaluation is aimed at results of curriculum implementation including academic achievement, skills achievement, life educational achievement and activity performance achievement. Process evaluation is aimed at curriculum development process containing stage of curriculum development, implementing process each stage and its work list to make an assessment by logical and comprehensiveness analysis. The list of content evaluation is aimed at curriculum framework, teaching materials for course use, satisfaction with teaching, satisfaction with equipments and satisfaction with teaching environment.

\section{B. Development Outcome}

According to the purpose of the plan, state the results of plan development. Curriculum planning respectively, module 
teaching material of science and technology base for the 1st grade, module teaching material of emerging technology introduction for the first grade, all of module teaching materials for the second grade, Project Practice plan and learning outcome assessment plan for the third grade.

TABLE I: PROJECT PRACTICE CURRICULUM PLANNING

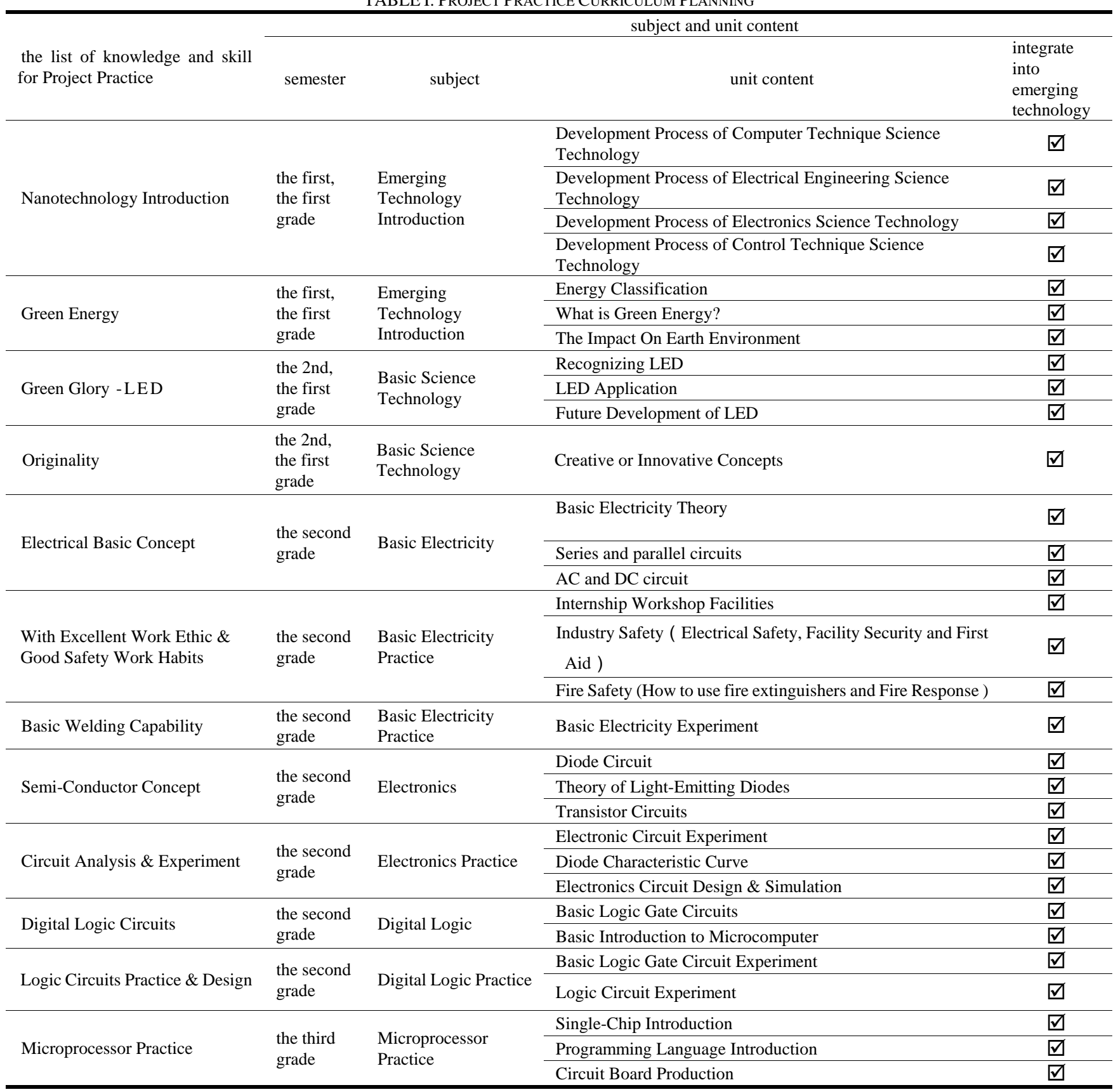

\section{Curriculum Planning}

Curriculum framework: Integrate emerging technology into courses containing professional subjects and practical subjects for the first grade to the third grade.

Project Practice curriculum planning and review: Knowledge and skill content for project needs and related subjects \& units are shown as Table I. Implementing results, review analysis of Project Practice curriculums are as follows:

\section{Implementation Review}

Developing Innovative Curriculums of the research are main application project of combining electronics diodes principle and light-emitting diodes LED. It is not very difficult in line part of circuit theory. Electric circuit in many of circuit training courses can be found the relative circuit. But this project is to hope students to understand LED circuit design and how to use it, also let students know energy is limited. How to save energy and upgrade the efficiency of energy use, economy and security, play unlimited creativity, let LED play its maximum functionality and value.

This project is completed by vocational students. Because of only three hours of the scheduled class lessons, time slightly is inadequate. In addition, this course is not the entrance examination subjects, students actively make it with a not strong willingness. Although electric circuit design is not difficult, circuit arrangement and beautify of product appearance need to be strengthened. At last the project report is finished, but its contents still have many to be reinforced. 
Nonetheless, let students know how to accomplish a project report.

\section{CONCLUSIONS AND SUGGeStions}

\section{A. Conclusions}

According to the purpose of this research, conclusions are summarized as follows:

Scientific Inquiry integrating into Project Practice curriculums that this research developed for vocational education have the following benefits: 1. Questionnaire development of Vocational High School students in science and technology literacy, conduct research and analysis to realize science and technology literacy of Vocational High School students to be a reference for launching science and technology education of Vocational High School students. 2. Verify Scientific Inquiry of Vocational High School students, development mode of Project Practice curriculums and make an assessment. 3. Verify Scientific Inquiry of Vocational High School students, curriculum teaching of Project Practice and assessment methods. 4. Amend Project Practice capacity scales, performing research and analysis to verify inquiry-based teaching strategies and its effect. 5. Amend Scientific Inquiry capacity scales, performing research and analysis to verify inquiry-based teaching strategies and its effect. 6. Amend Scientific Inquiry team work scales, performing research and analysis to verify inquiry-based teaching strategies and its effect. 7. Vocational High School students' Scientific Inquiry and curriculum development of Project Practice - teaching strategies - assessment methods and tools from this study could be a domestic reference for launching science and technology education of Vocational High School students. 8. Integrating materials technology, life technology and environmental technology to be the axes for Project Practice course connotation of science and technology education that could be a domestic reference for launching science and technology education of Vocational High School students.

There are contributions about academic theory, economic development and other applications. 1. Implement planning and improvement of Scientific Inquiry in teaching strategies of Project Practice. 2. Promote problem solving of practical abilities and problem solving of experiences \& technique for teaching needs. 3. Train professionals with technology literacy for vocational education needs. 4. Strengthen planning of researchers to cooperative learning model and teaching strategies for students of vocational education. 5 . Enhance teachers \& students of Vocational High School the interest of Scientific Inquiry strategies and practical operation ability. 6. Enrich teachers of Vocational High School using resources of inquiry teaching strategies and the ability of constructing assessment. 7. The information obtained in this study will provide a reference for other vocational education research to help to upgrade the quality of academic research for vocational education.

\section{B. Suggestions}

Strengthen students the circuit design of light-emitting diodes and SMD element welding practice in electronics practice application course of LED in the semester 2 of the second grade to enhance their understanding to different light-emitting diode application circuit and the ability of circuit practicing.

Strengthen students analyzing the characteristics of the different LED to short their time of designing LED application circuit in the production process of light-emitting diodes in electronics practice of the semester 2 of the second grade.

Add Project Practice subject to be a compulsory course for the third grade to allow students to make a project seriously.

\section{ACKNOWLEDGMENT}

The project was funded by the Ministry of Science and Technology under Grants NSC 102-2511-S-018 -010.

\section{REFERENCES}

[1] R. D. Anderson, "Reforming science teaching: what research says about inquiry," Journal of Science Teacher Education, vol. 13, no. 1, pp. 1-12, May 2002.

[2] A. M. Bodzin and W. M. Cates, "Inquiry dot Com," The Science Teacher, vol. 69, no. 6, pp. 23-31, 2002.

[3] B. A. Crawford, "Embracing the essence of inquiry: new roles for science teachers," Journal of Research in Science Teaching, vol. 37, no. 9, pp. 916-937, 2000.

[4] H. Gardner, "Reflections on multiple intelligences," Phi Delta Kappan, vol. 77 , no. 3, pp. 200-208, July 1995.

[5] L. Martin-Hansen, "Defining inquiry: exploring the many types of inquiry in the science classroom," The Science Teacher, vol. 69, no. 2, pp. 34-37, Dec. 2002.

[6] A. Rivert and R. Schneider, "Exploring the role of digital photography to enhance student inquiry in a local ecosystem," Journal of Computers in Mathematics and Science Teaching, vol. 23, no. 1, pp. 47-65, Sept. 2004.

[7] G. H. Roehrig and A. L. Fulie, "Constraints experienced by beginning secondary science teachers in implementing scientific inquiry lessons," International Journal of Science Education, vol. 26, no. 1, pp. 3-24, July. 2004.

[8] C. F. Rop, "The meaning of student inquiry questions: a teacher beliefs and responses," International Journal of Science Education, vol. 24, no. 7, pp. 717-736, Jan. 2002.

[9] F. R. Watson, R. L. S. Fulian, and C. McRobbie, "Students' discussions in practical scientific inquiries," International Journal of Science Education, vol. 26, no. 1, pp. 25-45, May. 2004.

[10] C. R. Pearce, Nurturing Inquiry: Real Science for the Elementary Classroom, Portsmouth, NH: Heinemann, 1999, ch. 6, pp. 206-221.

[11] F. X. Sutman, "Seeking more effective outcomes from science laboratory experiences (Grade 7-14): Six companion studies," presented at the annual meeting of the National Association for Research in Science Teaching, 1996, ch. 3, pp. 89-97.

[12] National Research Council, National science education standards, Washington, DC: National Academy Press, 1996, ch. 4, pp. 35-49.

[13] National Research Council, Inquiry and the National Science Education Standards: A guide for teaching and learning, Washington, DC: National Academy Press. 2002, ch. 5, pp. 135-149.

[14] J. S. Bruner, Toward a theory of instruction, Cambridge, Mass, Belknap Press of Harvard University, 1996, ch. 3, pp. 26-33.

[15] R. Driver, J. Leach, R. Millar, and P. Scott, Young people's images of science, Philadelphia, PA: Open University Press, 1996, ch. 4, pp. 56-55.

[16] W. M. W. So. (May, 2014). Constructive teaching in primary science. Asia-Pacific Forum on Science Learning and teaching. [Online]. 3(1). Available: http://www.ied.edu.hk/apfslt/v3_issue1/sowm/index.htm.

[17] S. Duggan and R. Gott, "Understanding evidence in investigations: the way to a more relevant curriculum?" Science Teaching, London: Routledge Falmer, 2000, ch. 1-2, p. 69.

[18] R. A. Duschl, "Making the nature of science explicit," in Improving science education, R. Millar, J. Leach, and J. Osborne (eds.) Buckingham: Open University Press, 2000, ch. 4, pp. 187-206.

[19] K. Goodnough and M. Cashion, "Fostering inquiry through problem-based learning," The Science Teacher, vol. 70, no. 9, pp. 21-25, July. 2003.

[20] D. Hodson, "Leraning from the past; lessons for the future: science education across the Millennium," Education Matters, Hong Kong: 
Faculty of Education, The University of Hong Kong, 2004, vol. 2, no. 2.

[21] Z. Kanari and R. Millar, "Reasoning from data: how students collect and interpret data in science investigations," Journal of Research in Science Teaching, vol. 41, no. 7, pp. 748-769, Sept. 2004.

[22] R. W. Bybee and N. M. Landes, "The biological sciences curriculum study (BSCS)," Science and Children, vol. 25, no. 8, pp. 36-37, 1988.

[23] W. Harlen, The Teaching of Science in Primary Schools, 3rd ed., London: David Fulton, 2000, ch. 3, pp. 66-79.

[24] M. Hollins and V. Whitby, Progression in primary science: a guide to the nature and practice of science in Key Stages 1 and 2, London: David Fulton Publishers. 2001, ch. 2, pp. 63-72.

[25] J. S. Krajcik, P. Blumenfeld, R. Marx, and E. Soloway, "Instructional, curricular, and technological supports for inquiry in science classrooms," in Inquiry into inquiry science learning and teaching, J. Minstrell and E. V. Zoo Eds., Washington, DC: American Association for the Advancement of Science Press, 1999, ch. 6, pp. 203-228.

[26] J. S. Krajcik, C. M. Czerniak, and C. F. Berger, Teaching science in elementary and middle school classrooms: a project-based approach, 2nd ed., US: McGraw-Hill, 2003, ch. 4, pp. 56-55.

[27] A. E. Lawson, Science teaching and the development of thinking, Belmont, California: Wadswoth Publishing Co., 1995, ch. 6, pp. 173-189.

[28] R. Schneider and J. Krajcik, "Supporting science teacher learning: The role of educative curriculum materials," Journal of Science Teacher Education, vol. 13, no. 3, pp. 221-245, Sept. 2002.

[29] L. Sternadel, "Inquiry and developing interpretations from evidence," The Science Teacher, vol. 71, no. 4, pp. 38-41, June, 2004.

[30] P. Tamir and V. N. Lunetta, "Inquiry related tasks in high school science laboratory handbooks," Science Education, vol. 65, pp. 447-484, March, 1981.

[31] R. Lazarowitz and P. Tamir, "Research on using laboratory instruction in Science," in D. L.Gabel (ed.), Handbook of research on science teaching and learning, New York: MacMillan Publishing Company, 1994, ch. 2, pp. 94-128.

[32] J. W. Lindfors, Children's inquiry: using language to make sense of the world, New York: Teachers College Press. 1999, ch. 3, pp. 3-22.

[33] K. E. Metz, "Scientific inquiry within reach of children," in B. J. G Fraser and K. G. Tobin eds., International handbook of Science Education, 1998, ch. 2, pp. 81-96.

[34] P. Warwick, "Developing a scientific way of working with younger children," in P. Warwick and R. S.Linfield Eds., Science 3-13: The past, the present, and possible futures, London : Routledge Falmer, 2000, pp. 49-63.

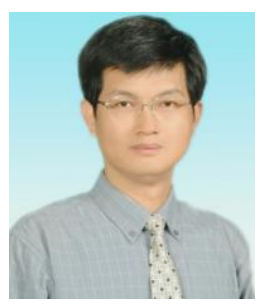

Chin-Wen Liao received his M.S. and Ph.D. in industrial education from National Taiwan Normal University, Taiwan, R.O.C. in 1994 and 2002, respectively. Since August 2011, he has been a professor in Department of Industrial Education and Technology at National Changhua University of Education (NCUE) in Taiwan, R.O.C. He teaches courses in technology and vocational education, energy education, course and teaching, organizational learning. His research interests include technology and vocational education, teacher education, energy education of technology, and learning organization.

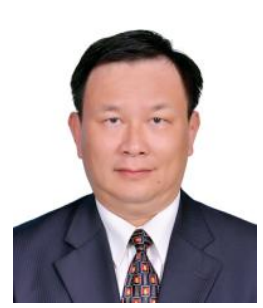

Yao-Tsung Chiang received M.S. degree in agricultural machinery engineering from National Chung Hsing University in 2002, and currently is a doctoral student of the Department of Industrial Education and Technology at National Changhua University of Education (NCUE). Since August 2009, he had been the principal of National Chia-Yi Industrial Vocational High School until 2013, then transferred to be the principal of National Wufeng Agricultural and Industrial Vocational High School. Since August 1984, he has taught courses in agricultural machinery, mechanical drawing, introduction of computer science, frozen food machinery and introduction of machinery in National Yuanlin Agricultural and Industrial Vocational High School until 2009.

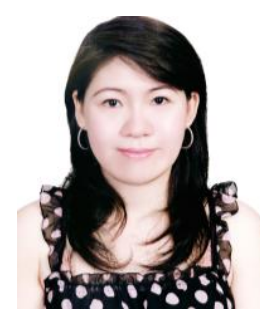

Yi-Chen Chang received M.S. from Graduate Institute of Technology and Vocational Education National Taipei University of Technology in 2009, and is studying Ph.D. in Department of Industrial Education and Technology at National Changhua University of Education (NCUE) in Taiwan, R.O.C. respectively. Since August 2008, she served the position as the director in Department of Fashion and Styling Design at Chungyu Institute of Technology in Taiwan, R.O.C. She is the director of Department of Fashion and Styling Design at Yuda University of Science and Technology from 2011 until now. She teaches courses in hairdressing and cosmetology. Her research interest is technology and vocational education.

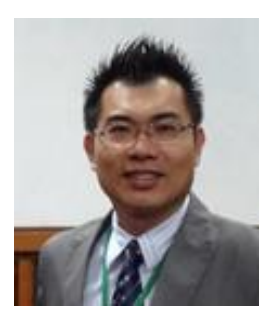

Tsai-Ku Liao received M.S. degree at the Department of Geography from National Taiwan Normal University in 2006, and currently is a doctoral student of the Department of Industrial Education and Technology at National Changhua University of Education (NCUE), Taiwan, R.O.C. Since August 2008, he has been a director of Student Affairs and Library in National Taichung First Senior High School (TCFSH) in Taiwan, R.O.C. Since August 1998, he has taught courses in Geogrpahy, GIS, Monographic study in the same school. 